\title{
Contrasting responses of two xerophilous land snails to fire and natural reforestation
}

\author{
Xavier Santos ${ }^{1,2,4}$, Vicenç Bros ${ }^{3}$, Elisabet Ros ${ }^{3}$

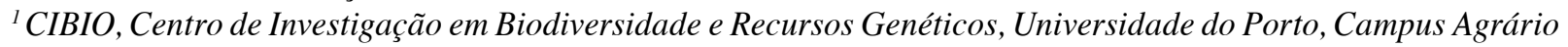 \\ de Vairão, 4485-661 Vairão, Portugal \\ ${ }^{2}$ Departament de Biologia Animal, Universitat de Barcelona, Av. Diagonal 645, E-08028 Barcelona, Spain \\ ${ }^{3}$ Parc Natural de Sant Llorenç del Munt i l'Obac, Oficina Tècnica de Parcs Naturals, Diputació de Barcelona, \\ c/Urgell 187, Edif. Rellotge 3a, E-08036 Barcelona, Spain \\ ${ }^{4}$ E-mail: xsantossantiro@gmail.com
}

Key words: burnt areas, Mediterranean basin, terrestrial gastropods, wildfires, Xerocrassa spp.

\begin{abstract}
Land-use change is considered the main disturbance in landscape structure and composition, directly affecting faunal distribution and species richness worldwide. Wildfires and natural reforestation alter habitat structure in terms of vegetation cover and also in soil composition and moisture; these processes hence trigger habitat transformations that act as opposing forces at small spatial scales. We have explored the contrasting effects of wildfires and natural reforestation on two land-snail species of the genus Xerocrassa, which are endemic in the western Mediterranean. Snails were sampled in pine and Holm oak forest, stony bare slopes and burnt sites. Both species followed a similar pattern: they were present in more than $75 \%$ of the stony bare slope sites and around 50\% of the burnt sites, but were almost absent in Holm oak forests. The comparison of aerial photographs from 1956 and 2003 showed that stony bare slopes were significantly larger in 1956 , this indicating that the natural reforestation might close these habitats, and consequently threaten the viability of the Xerocrassa populations. Given their limited mobility, the presence of Xerocrassa at burnt sites suggests that these species live in small and cryptic populations within the forest, surviving fire and expanding their distribution due to the appearance of adequate habitats. Our study shows that natural reforestation and fire play opposing roles in conserving Xerocrassa populations. The preservation of stony bare slopes as well as other open areas is a key management guideline to maintain landscape mosaics and help future conservation of species of open habitats such as these vulnerable endemic gastropods.
\end{abstract}

\section{Contents}

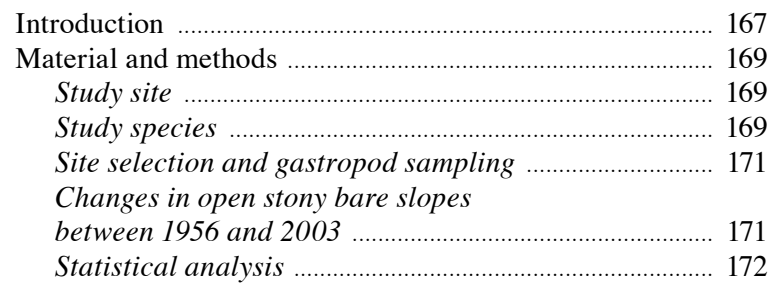

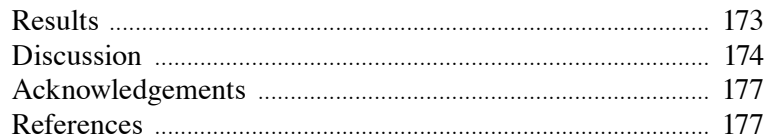

\section{Introduction}

Over one-fifth of the land area of the globe has been converted to human-dominated uses (Hoekstra et al., 2005). Land-use change is considered the main process disturbing the structure and composition of the landscape, directly affecting the faunal distribution and species richness in many taxonomic groups (Parody et al., 2001; Dupouey et al., 2002; Ribeiro et al., 2009). The Mediterranean basin has been altered by human activities for at least 5,000 years (Bottema et al., 1990; Blondel et al., 2010), and the impact of these activities has caused transformation, fragmentation, degradation, and loss of natural habitats, which have threatened at least $15 \%$ of all endemic animals and plants (Brooks et al., 2002). Thus, land-use change is considered the factor with the strongest impact on the loss of biodiversity in Mediterranean ecosystems (Sala et al., 2000).

A particular case of habitat alteration is fire. Wildfires are natural disturbances that have shaped vegetation structure and influenced associated faunas in almost all regions in the world (Bond et al., 2005). In Mediterranean ecosystems, wildfires are common natural perturbations, and a fundamental element for understanding the functioning and structure of these ecosystems (Moreno and Oechel, 1994; Trabaud and Prodon, 2002). Fire affects natural animal communities by causing direct mortality during fire and indirect deaths by changes in post-fire habitat structure (Whelan, 1995; Broza and Izhaki, 1997; Buddle et al., 2006). However, a mosaic of different post-fire succession 
stages promotes habitat heterogeneity, and this in turn facilitates biodiversity conservation (Bradstock et al., 2005; Driscoll et al., 2010). Given that species greatly diverge in habitat requirements, a heterogeneous landscape driven by fire-mosaic dynamics may support high biodiversity with a number of species adapted to different stages of postfire succession (Moretti et al., 2004; Driscoll and Henderson, 2008; Santos and Poquet, 2010). Understanding mechanistic causes of this heterogeneous response is a conservation concern for the management of wildlife reserves heavily affected by fire (Driscoll et al., 2010).

Terrestrial gastropods are an appropriate model group for evaluating their response to fire as they are highly sensitive to changes in vegetation structure due to their dependence on moisture (Cook, 2001; Heller, 2001). This dependence make snails extremely vulnerable to wildfires and provokes major diver- sity losses after fire (Nekola, 2002; Kiss et al., 2004; Severs, 2005; Kiss and Magnin, 2003, 2006; Santos et al., 2009; Bros et al., 2011). Although most snail species from temperate regions depend on moisture (Kerney and Cameron, 1999), some are adapted to dry habitats. For example, during the first post-fire years, when habitat structure is very simple, dominant snails in burnt localities from southern France are xerophilous species (Kiss et al., 2004). In boreal American dry forests, prescribed fires have resulted in fine-scale mosaics acting as refuges for the endemic mountainsnail genus Oreohelix (Gaines et al., 2011); this management restores mountainsnail habitats and avoids large and severe fires. Thus, through post-fire succession, contrasting responses are expected from land-snail species in parallel to changes in habitat structure.

We have investigated this issue in a Mediterranean
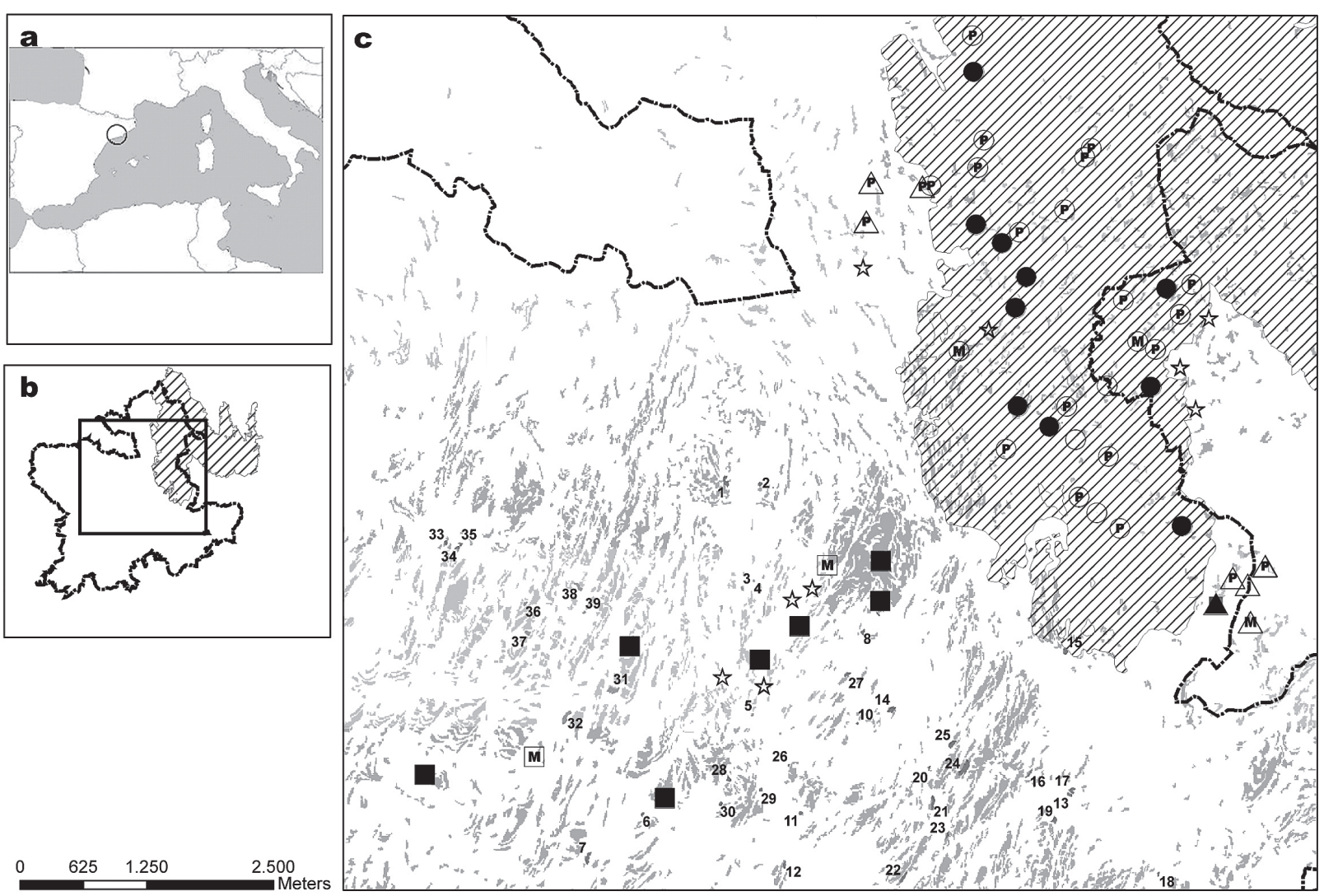

Fig. 1. Geographic location of the study area in southwestern Europe (a), area burnt in 2003 (grey area) with respect the Natural Park perimeter (dotted line) (b) and distribution of sites sampled (c). In (c), the grey areas show the distribution of stony bare slopes in the park, whereas numbers represent slopes measured from aerial photographs in 1956 and 2003. Symbols of the sites are: Holm oak forest (circles), pine forest (stars), stony bare slope (triangles) and burnt sites (rhomboids). Open symbols represent sites without snails, black symbols those with both species, and $\mathrm{M}$ and $\mathrm{P}$ those with the presence of only $X$. montserratensis or $X$. penchinati, respectively. 
reserve severely affected by summer fires. The objective of our study was to examine the response of two xerophilous species of the genus Xerocrassa to fire and natural reforestation in Sant Llorenç del Munt i l'Obac Natural Park. We have specifically sought to identify the factors of the habitat structure that determine presence/absence of these snails in forest, open, and burnt sites. Such information may help explain the mechanistic responses of these species to fire and natural reforestation and may aid managers in making decisions to enhance biodiversity conservation in fireprone areas (Driscoll et al., 2010). The two endemic Xerocrassa species in the park are valuable in terms of conservation, and these results will be relevant to evaluate threats related to natural perturbations, and to propose management guidelines for the correct conservation of their populations.

\section{Material and methods}

Study site

The study site was located in St Llorenç del Munt i l'Obac Natural Park, Barcelona province, north-eastern Spain (Fig. 1A). This reserve, located in the Catalan Pre-coastal Mountain Range, has a total area of 13,694 hectares. The landscape of the park is rugged, with prominent conglomerate crags and monoliths. The highest peak is La Mola (1,104 m). The lithology of the park is very uniform, namely a polymictic conglomerate ground composed by a deposition of pebbles from a varied origin later being cemented by an argillaceous matrix. Calcareous conglomerates are much less abundant and differentiated by the whitish colour due to dominance of calcareous matter (Badia et al., 2009). The erosive action on these types of rock gave the park its unique relief, characterised by narrow valleys, and stony bare slopes and monoliths surrounded by a Holm oak forest. The climate of the study area is subhumid Mediterranean with annual rainfall of around $600 \mathrm{~mm}$ (Panareda and Pintó, 1997). Rainfall is higher in spring and autumn than in summer. Thus, the area is prone to fast-spreading fires during hot, dry summers.

The original forest tree in the park is Holm oak Quercus ilex L., 1753, in some parts mixed with Q. Coccifera L., 1753 and $Q$. x cerrioides Willk. \& Costa, 1859. Peripheral lowland areas were covered by vineyards during early $20^{\text {th }}$ century, and after the Phylloxera plague the grapevines were replaced by pines Pinus halepensis Mill., 1768 and plantations of Pinus nigra Arnold, 1785. The pine forest has Holm oak underbrush. In August 2003, $10 \%$ of the park burned during a summer fire that affected 4,443 ha with 1,778 ha of this lying inside the park (Fig. 1B). Impelled by wind, the blaze spread quickly, burning the entire area in just one day (10th August 2003). Almost all the burnt area was dominated by a pine forest with Holm oak underbrush. After the fire, charred areas were occupied by dense scrub dominated by Mediterranean shrub species such as Cistus albidus L., 1753, Rosmarinus officinalis L., 1753, Dorycnium pentaphyllum Scop., 1771, Rubus ulmifolius Schott, 1818, Genista scorpius (L., 1805), Pistacia lentiscus L., 1753, and Coriaria myrtifolia L., 1753. Resprouter trees such as Arbutus unedo L., 1753 and other plants such as Echium vulgare L., 1753, Convolvulus arvensis L., 1753, Aphillantes monspeliensis L., 1753, Anagallis arvensis L., 1753, Helianthemum oelandicum (L., 1802), Leontodon taraxacoides (Vill.) Mérat, 1831, Ononis natrix L., 1753, Psoralea bituminosa L., 1753, Linum sp., and Euphorbia sp. were found in the underbrush but increased their abundance after fire due to their reprouting or seedling capacity, a common trait in many Mediterraean plant species. Grasses such as Brachypodium phoenicoides Roemer \& Schultes, 1817 and Brachipodium retusum (Pers.) Beaur., 1812 also were commonly found in burnt areas.

One the most characteristic habitats in the Park are stony bare slopes, called 'codines' in Catalan. This xerophilous habitat is found usually on hills and mountain tops over $700 \mathrm{~m}$ altitude, and it has thin soil layer. Usually this habitat shows a patchy and isolated distribution, with rupicolous vegetation surrounded by Holm oak forest. This habitat occupies 590 ha of the park (4.3\% of the Park surface), although it holds a particular fauna and flora, which significantly contributes to the biodiversity of the entire Natural Park (Badia et al. 2009). The plant community is composed by species such as Arenaria conimbricensis Brot. 1800, Erodium foetidum ssp. glandulosum (Cav.) Willd., 1800, Sedum album L., 1753, Narcissus assoanus Dufour, 1830, Dipcadi serotinum (L.) Medicus, 1790, and Thymus vulgaris L., 1753 (Panareda \& Pintó, 1997; Badia et al., 2009).

\section{Study species}

The gastropod community in Sant Llorenç del Munt i l'Obac Natural Park includes more than 90 terrestrial and freshwater species, forest and rupicolous specialist species being dominant (Bros, 2000). The gastropod 

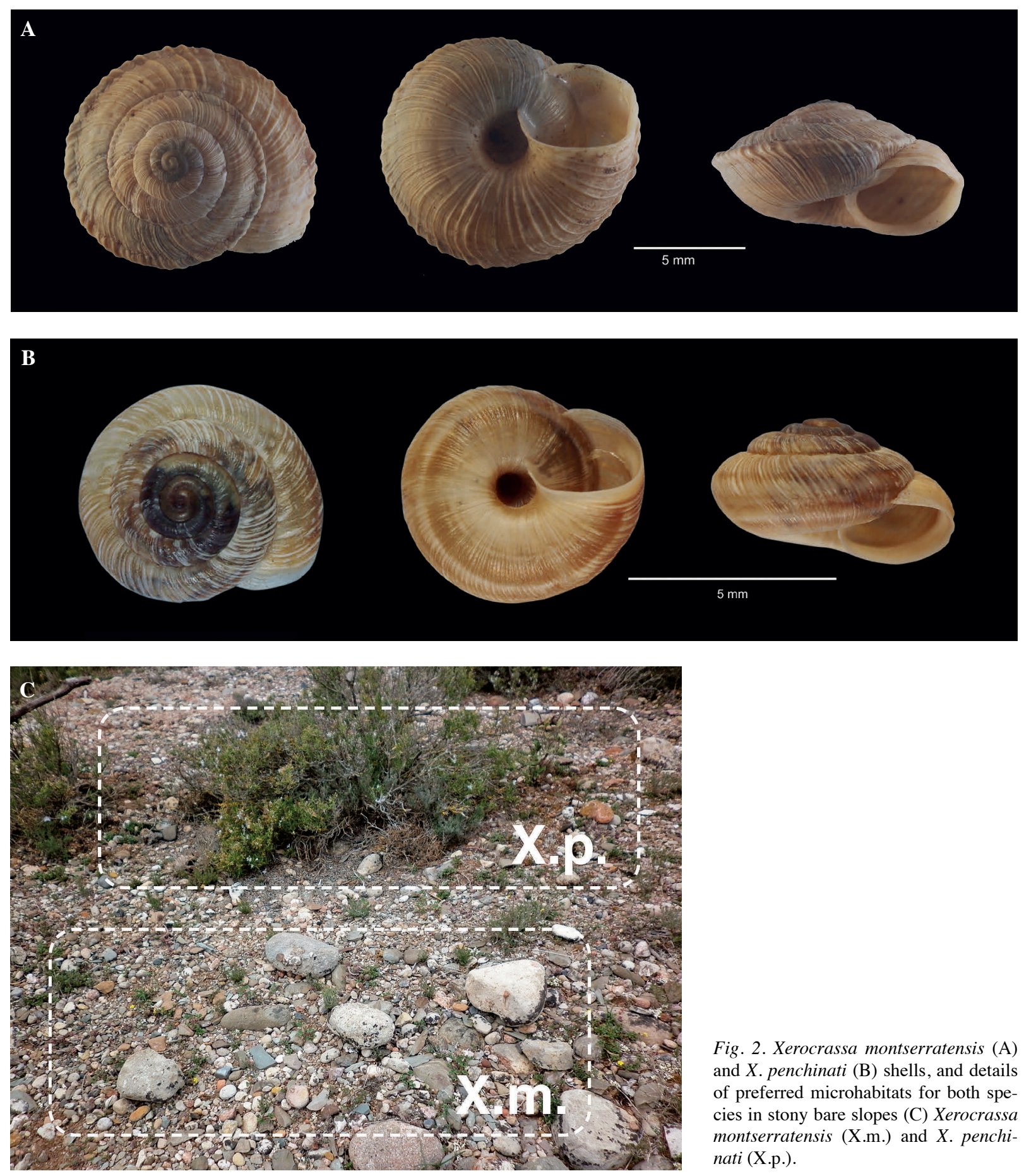

Fig. 2. Xerocrassa montserratensis (A) and $X$. penchinati (B) shells, and details of preferred microhabitats for both species in stony bare slopes (C) Xerocrassa montserratensis (X.m.) and X. penchinati (X.p.).

community includes two species of the genus Xerocrassa Monterosato, 1892 (Gastropoda, Hygromiidae). In the Iberian Peninsula, this genus is represented by 20 endemic species and often with very restricted distributions (Bank, 2011). The study site is occupied by two species of this genus: $X$. montserratensis and $X$. penchinati.

Xerocrassa montserratensis (Hidalgo, 1870) is a small snail (shell diameter: 7-12 $\mathrm{mm}$ ) with a polymorphic and heavily striated shell, 5-6 spire whorls 
(Fig. 2A), and occupies xerophilous habitats (Bros, 2000). Our preliminary studies reported that this snail prefers habitats with abundant medium-sized loose rocks produced by the erosion of the conglomerate substrates (Bros, 2006). This species has a restricted distribution, being found exclusively in three nearby mountainous natural parks: Montserrat, Sant Llorenç del Munt i l'Obac, and Serralada de Marina (Martinez-Ortí and Bros, 2011). Based on its restricted distribution, habitat fragmentation, and low ability to recolonize restored habitats, it is listed as Endangered in the IUCN Red List of threatened Species (Martínez-Ortí, 2011).

Xerocrassa penchinati (Bourguignat, 1868) shows morphologic and ecologic traits similar to those of $X$. montserratensis. This is also a small snail, with a delicately striated shell of 5-6.5 mm in diameter and 4-5 spire whorls (Fig. 2B; Kerney and Cameron, 1999; Clanzing and Bertrand, 2000; Bragado et al, 2010). This snail prefers habitats that include calcareous soil with scarce vegetation, Mediterranean shrub, degraded pine forests, and open areas with abundant grass and stones. In these habitats, the species is found in several ground microhabitats such as under stones larger than $20 \mathrm{~mm}$ in diameter (Clanzing and Bertrand, 2000) and near the scrub roots during the summer dry periods $(\mathrm{V}$. Bros, pers. obs.). This snail is endemic of the northwestern Iberian Peninsula, with isolated populations in some Mediterranean coastal sites at Southern France (Clanzing and Bertrand, 2000).

\section{Site selection and gastropod sampling}

In May-June 2007, four years after the summer fire, we started a stratified sampling at 62 sites (Fig. 1C) including Holm oak forest $(n=11)$, pine forest $(n=9)$, stony bare slopes $(n=9)$, and burnt areas $(n=33)$. Holm oak and pine sites were selected as representative of major woodland habitats in the park, whereas stony bare slopes had been previously reported as adequate habitats for Xerocrassa species in the park (Bros, 2000, 2006). All the burnt sites were pine forests before the 2003 fire.

All the sites were selected in polymictic conglomerate ground, flat areas, and similar slope orientation (from southwestern to southeastern). In a subsample of 20 out of 62 sites (stony bare slopes were not examined), we did not find differences in soil $\mathrm{pH}$, electrical conductivity $\left(\mathrm{dS} \mathrm{m} \mathrm{m}^{-1}\right) \% \mathrm{C}$, and $\% \mathrm{~N}$ (Kruskal-Wallis test $\mathrm{H}=$ $2.29, P=0.51 ; \mathrm{H}=3.86, P=0.28 ; \mathrm{H}=4.49, P=0.21 ; \mathrm{H}$ $=0.98, P=0.81$, respectively; Tere Sauras, unpublished data). Charcoal remains after the fire are expected to produce increased carbon content in soil (Kappes et al., 2012), although in our study area, \% C did not vary between unburnt and burnt sites four years after the fire (Tere Sauras, unpublished data), probably because postfire logging removed a significant part of charcoal.

Site selection was limited by the distribution of each habitat type in the Park, although sites were selected in order to avoid spatial autocorrelation on snail occurrence and abundance. For example, most stony bare slopes are in the center of the park and hence some Holm oak sites were selected close to them, whereas the 2003 fire occurred in the eastern part of the Park and consequently some pine and Holm oak sites were selected in the fire edge (Fig. 1C).

At each site, Xerocrassa snails were actively searched for by hand for 20 min within a $15 \times 15 \mathrm{~m}$ square, turning over stones and coarse woody debris. According to Ward-Booth and Dussart (2001), this sampling method is appropriate for snail species with shells larger than $3 \mathrm{~mm}$ and Xerocrassa species in the natural park are over $3 \mathrm{~mm}$ of shell size.

Vegetation structure has been shown to influence snail abundance and diversity (Coppolino, 2010). Thus, habitat structure of sampling sites was characterized by recording several vegetation and ground-cover variables along a longitudinal 50-m transect that crossed the $15 \times 15 \mathrm{~m}$ squares used for snail searches. We recorded the extent of four vegetation types (Holm oak [HOLM] and pine [PINE] trees, extent of shrubs [SHRUB] and grass [GRASS]) and three groundcover types (leaf-litter from tree and shrub species [LITTER], bare ground [BARE] and refuges [REFUGE]) at points $50 \mathrm{~cm}$ apart along that transect. Thus, each vegetation and groundcover type is measured as the number of contacts along transects and consequently represents their relative abundances on transects. Any kind of stone larger than $10 \mathrm{~cm}$ in diameter, or any dead trunk was considered a refuge, since these are the preferred microhabitats for Xerocrassa species (Bros, 2006). Habitat structure was characterized with these vegetation and groundcover variables since their influence on the abundance and diversity of snail communities in the Mediterranean basin has been reported by several authors (e.g. Magnin et al., 1995; Ondina and Mato, 2001; Labaune and Magnin, 2002).

\section{Changes in open stony bare slopes between 1956 and 2003}

Given that stony bare slopes are very suitable for Xerocrassa species (Bros, 2006), the temporal dynamics 

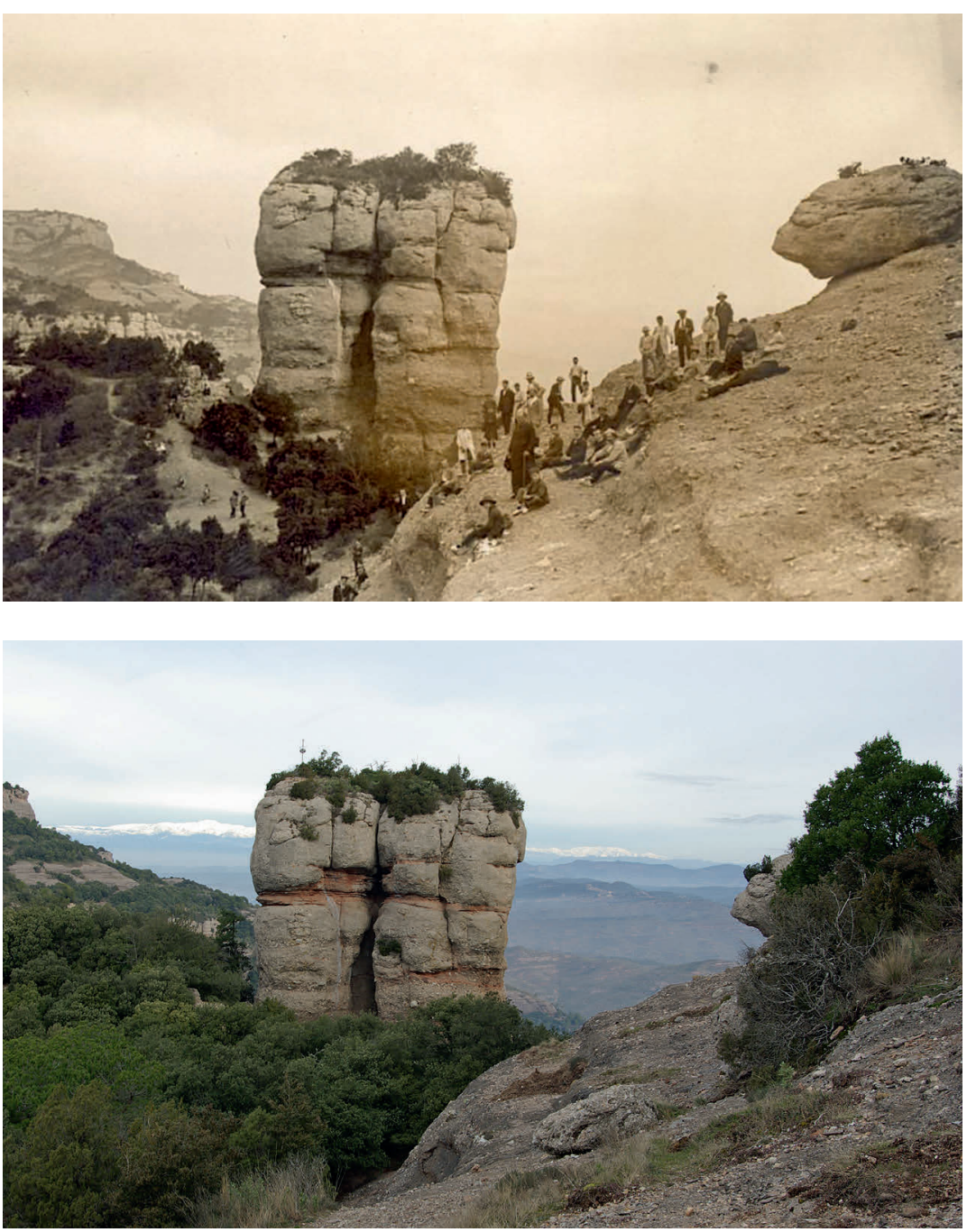

Fig. 3. A famous site in the natural park called 'Morral del Drac' circa 1910 and in 2008. In the more recent photograph, it is possible to discern the incremental growth of Holm oak forest. (degree of reduction or amplification) of these narrow habitats were estimated for the last 50 years in the park by comparing aerial photographs taken in 1956 and 2003. The 1956 photo was the first aerial photo taken in this region. Both photographs were geo-referenced, and 39 open-rocky points were randomly selected (Fig. 1C) and their surface areas were measured with ArcGIS tools. Stony bare slopes were selected randomly across the park although selection was constrained by the quality of the photograph made in 1956; those points with high slope and especially those without clear limits in the photograph made in 1956 were excluded to avoid mistakes in surface estimate. Differences in the surface areas of these sites between 1956 and 2003 were compared by a Wilcoxon Matched Pairs Test.

\section{Statistical analysis}

The relationship between the vegetation variables and the four habitats defined were analysed using CANO$\mathrm{CO}$ for Windows (version 4.55; ter Braak and Šmilauer, 2002). The linear or unimodal relation between variables and habitats was tested by a Detrended Correspondence Analysis (DCA). We found that the largest DCA gradient was 2.957, indicating that the distribution was linear, since a Canonical Correspondence Analysis (CCA), which assumes unimodal distribution of the data, is not adequate when the length of gradient (estimated with a DCA) is smaller than 4 (ter Braak and Šmilauer, 2002; Lepš and Šmilauer, 2003). Therefore, we analysed the relation between vegetation and groundcover variables and habitats by a Redundancy 
Analysis (RDA), statistically testing the relationship between the axes and variables by a permutation Monte Carlo test (ter Braak and Šmilauer, 2002).

How vegetation and groundcover variables affected the presence and abundance of Xerocrassa species was examined in two steps. In the first step, we tested whether the vegetation and groundcover variables differed between samples with presence and absence of the Xerocrassa species by using Student's t-test or Mann-Whitney U-test (M-W U-test) when variables did not fit normality and homoscedasticity of variances. In the second step, we used Generalized Linear Models (GLZ) to analyse the effect of the vegetation and ground-cover variables on $X$. montserratensis and $X$.penchinati abundances using Poisson error distributions and a log link function, due to the number of sites without snails. From the GLZ, we regarded the standardized regression coefficients of variables to see the sign of their effects on the abundance of Xerocrassa species. Before the analyses, the variable LITTER was removed as it was heavily correlated with HOLM. The other variables were maintained as $r<0.60$ in all the pairwise correlations, and therefore it is improbable that multicollinearity affected the statistical results.

Assumptions of parametric tests (normality, homoscedasticity of the variances) were tested for each variable before the analysis. Observed versus expected frequencies in the presence-absence of Xerocrassa sp. in the four habitats sampled were compared by $\chi^{2}$ -tests. Mean values are followed by \pm standard error, and we set alpha equal to 0.05 for significance in all tests. Analyses were performed with STATISTICA (version 6.0).

We tested for non-random patterns of Xerocrassa species co-occurrence with EcoSim 7.0 (Gotelli and Entsminger, 2001). The input for the co-occurrence analysis is a presence-absence matrix. As there are a number of sites without both Xerocrassa species, we decided to use a degenerate matrix procedure which accepts empty sites in the analysis. We calculated the Variance ratio (V-ratio) which in fact is an index of variability in species richness per site; when niche limitation constrains the number of coexisting species, the variance in species richness among sites will be small relative to the null model (i.e. V-ratio $=1.0$ as species are distributed independently and sites are equiprobable). V-ratio $<1.0$ means that there is a strong negative covariance between species pairs (i.e. species tend to exclude), whereas V-ratio $>1.0$ means that there is a positive covariance between species pairs (i.e. species tend to co-occur) (Gotelli and Entsminger,
2001). From our presence-absence matrix, Ecosim performed 1000 simulations and empty sites were included in the process. We compared our observed Vratio score with the distribution of the V-ratio scores obtained from simulations.

\section{Results}

After measuring the surface area of 39 stony bare slopes in the aerial photographs from 1956 and 2003, we detected 30 samples that had larger surface areas in 1956 and nine samples for which this was the case in 2003. Stony bare slopes had larger surface areas in 1956 (Wilcoxon $Z=3.32, n=39, p=0.0009$ ) as the canopy of the Holm oak forest surrounding these areas increased over time. The reduction of stony bare slopes was on average $15.18 \%$ of surface area. Differences in the extent of Holm oak forest were significant when old and recent photographs of some of the most popular monoliths in the natural park were compared visually (Fig. 3). According to the presence of Xerocrassa in the four habitats sampled (see below), temporal variation in stony bare slopes in detriment to Holm oak forest is expected to reduce the availability of preferred habitats for Xerocrassa snails.

The redundancy analysis (RDA) showed significant differences in the vegetation and soil structure among habitats $($ trace $=0.795, F$-ratio $=75.00, p=0.0001$ ). The greatest differences were between Holm oak forest and burnt sites, with a clear and significant discrimination on axis 1 (eigenvalue $=0.591, F$-ratio $=$ $83.66, p=0.0001$ ), whereas axis 2 also proved significant (eigenvalue $=0.139, F$-ratio $=29.94, p=0.0001$ ) and discriminated between pine forest sites and open bare slope sites (on-line supplementary material S1). Accordingly, several vegetation and groundcover variables were associated with habitats. For example, on axis 1, burnt sites were characterized by greater grass coverage, and Holm oak sites by a greater amount of litter. On axis 2, open rocky areas had more refuges and bare ground (on-line supplementary material S1). Xerocrassa montserratensis was recorded at 24 (38.7\%) sites, whereas $X$. penchinati was found at 41 (66.1\%). Their presence differed according to the habitats $(X$. montserratensis: $\chi^{2}=16.33, d f=3, p=0.001 ; X$. penchinati: $\chi^{2}=8.80, d f=3, p=0.03$ ) as both species were uncommon or absent at Holm oak forest and X. montserratensis also in pine forest, but common in open areas (stony bare slope and burnt sites) (Fig. 4). Accordingly, Student's t- /Mann-Whitney U-tests showed 


\begin{tabular}{|c|c|c|c|c|}
\hline & $\begin{array}{l}\text { Mean } \\
\text { Presence }\end{array}$ & $\begin{array}{l}\text { Mean } \\
\text { Absence }\end{array}$ & $\begin{array}{l}\text { t-value } \\
\mathrm{df}=60\end{array}$ & $\mathrm{Z}$ \\
\hline \multicolumn{5}{|c|}{ X.montserratensis } \\
\hline HOLM & $2.33 \pm 0.76$ & $23.03 \pm 5.59$ & & $2.69 * *$ \\
\hline PINE & $3.00 \pm 1.68$ & $11.95 \pm 3.36$ & & $1.9 *$ \\
\hline SHRUB & $25.96 \pm 3.81$ & $32.37 \pm 2.03$ & 1.62 & \\
\hline LITTER & $3.29 \pm 1.74$ & $23.37 \pm 4.96$ & & $2.62 * *$ \\
\hline BARE & $37.33 \pm 4.49$ & $19.74 \pm 2.33$ & & $3.13 * *$ \\
\hline GRASS & $23.96 \pm 2.35$ & $17.05 \pm 2.17$ & $2.09 *$ & \\
\hline REFUGE & $8.00 \pm 0.97$ & $8.47 \pm 1.14$ & 0.29 & \\
\hline \multicolumn{5}{|l|}{$X$. penchinati } \\
\hline HOLM & $2.37 \pm 0.52$ & $39.71 \pm 8.56$ & & $3.86 * *$ \\
\hline PINE & $6.73 \pm 2.70$ & $11.90 \pm 3.85$ & 1.11 & \\
\hline SHRUB & $31.29 \pm 2.38$ & $27.14 \pm 3.41$ & 1.01 & \\
\hline LITTER & $4.00 \pm 1.45$ & $38.24 \pm 7.30$ & & $4.08 * *$ \\
\hline BARE & $32.27 \pm 2.72$ & $15.38 \pm 4.16$ & $3.5 * *$ & \\
\hline GRASS & $21.61 \pm 1.82$ & $16.05 \pm 3.29$ & 1.61 & \\
\hline REFUGE & $9.10 \pm 0.99$ & $6.71 \pm 1.26$ & 1.44 & \\
\hline Variables & Estimate & S. E. & Wald Stat. & $\mathrm{p}$ \\
\hline \multicolumn{5}{|c|}{ X. montserratensis } \\
\hline Intercept & -1.446 & 2.053 & 0.496 & n.s. \\
\hline HOLMOAK & -0.089 & 0.041 & 4.814 & $*$ \\
\hline PINE & -0.046 & 0.022 & 4.182 & $*$ \\
\hline SHRUB & 0.010 & 0.022 & 0.187 & n.s. \\
\hline BARE & 0.041 & 0.022 & 3.504 & n.s. (0.06) \\
\hline GRASS & 0.043 & 0.021 & 4.240 & $*$ \\
\hline REFUGE & -0.017 & 0.026 & 0.449 & n.s. \\
\hline \multicolumn{5}{|l|}{$X$. penchinati } \\
\hline Intercept & -1.488 & 1.200 & 1.539 & n.s. \\
\hline HOLMOAK & -0.065 & 0.018 & 12.639 & $* *$ \\
\hline PINE & -0.005 & 0.007 & 0.404 & n.s. \\
\hline SHRUB & 0.046 & 0.013 & 12.443 & $* *$ \\
\hline BARE & 0.031 & 0.013 & 6.032 & $*$ \\
\hline GRASS & 0.020 & 0.012 & 2.712 & n.s. \\
\hline REFUGE & 0.059 & 0.013 & 19.560 & $* *$ \\
\hline
\end{tabular}

Table 1. Student's t-test or Mann-Whitney U-test comparisons of abundance in vegetation and groundcover types between sites with (presence) and without (absence) Xerocrassa montserratensis and $X$. penchinati. Values are means \pm SE.

Table 2. Results of the GLZ models for $X$. montserratensis and $X$. penchinati abundances and effects of the vegetation and groundcover variables measured in the sites sampled. See list of all variables in the Methods section. that both species were present at sites with a low abundance of Holm oaks (and leaf-litter) and a high abundance of bare ground (Table 1).

According to the GLZ results, the contribution of vegetation and groundcover variables on the abundance of the two Xerocrassa species demonstrated that Holm oak affected the abundance of both species negatively, and pine affected $X$. montserratensis abundance negatively. Moreover, grass cover increases the abundance of $X$. montserratensis, whereas extent of shrub, bare ground and number of refuges increases the abundance $X$. penchinati (Table 2).

The two species were absent from 16 out of 62 sites
(26\%), only one species was found in 27 sites (44\%) and both species in 19 sites (31\%). The co-occurrence analysis showed that the observed V-ratio was 1.2188, whereas the V-ratio mean after 1000 simulations was 1.0039 (variance 0.0164), which means that the two Xerocrassa species do not tend to exclude one to other.

\section{Discussion}

This study identifies the habitat requirements of two endemic and xerophilous gastropods, Xerocrassa montserratensis and $X$. penchinatti, in a protected 
Mediterranean area. Our results indicate that the two Xerocrassa species avoided Holm oak forest, common in the park and in many Mediterranean ecosystems, which often forms a very dense canopy. In addition, $X$. montserratensis appears to be more demanding in the habitat structure since the expansion of pines and scrubland has a negative impact on its presence.

Our co-ocurrence analysis indicates that the species do not mutually exclude. In fact, both species are absent in Holm oak forest although they cohabit in stony bare slopes where both species select particular microhabitats in accordance to their habitat requirements, namely bare ground and pebbles for $X$. montserratensis, and shrub for $X$. penchinati (Fig. 2C). GLZ results confirm these microhabitat preferences as $X$. montserratensis appears to be primarily dependent on open areas, whereas $X$. penchinati is more demanding in particular habitat structures such as the presence of shrubs and refuges. Despite the lack of information on basic ecological traits of both species (e.g. diet, activity patterns or physiological tolerance to drought), morphological variation in shell morphology (striation, size and number of spire whorls) might give insights on adaptive abilities to different microhabitats (Goodfriend, 1986; Schilthuizen, 2011). In fact, X. montserratensis and $X$. penchinati slightly differ in shell striation (deep and highly striated, and moderately striated), carene (present and absent) and form (more and less plane, respectively). These differences would be in accordance to more strict xerophilous microenvironments occupied by X. montserratensis (Giokas, 2008; Moreno-Rueda, 2011).

Many land-snail communities are very sensitive to plant community structure and soil properties (Dedov et al., 2006; Kappes et al., 2006), avoid habitats without detritus on the ground (Cook, 2001; Heller, 2001), and are highly diverse and rich in wet microhabitats with abundant vegetation and humus (Watters et al., 2005). However, the two Xerocrassa species analysed here are habitat specialists, preferring open areas with scarce vegetation. Specialization in life-history traits can make species vulnerable to extinction (McKinney, 1997; Davies et al., 2004; Santos et al., 2006), this pattern being even more critical for $X$. montserratensis due to its small distribution range (ICHN, 2008; Martinez-Ortí, 2011). For this reason, changes in the abiotic and biotic characteristics of the preferred habitats for the Xerocrassa species (e.g. increment of canopy, reduction of refuges) may affect the viability of their populations.

This study demonstrates that Xerocrassa snails pre- fer stony bare slopes. These rocky spots, originated by the erosive action of the water on the conglomerate matrix, are among the most distinctive geomorphological features of the Natural Park, and important biodiversity hotspots due to their particular fauna and flora with several species of conservation interest (Fig. 5 ; Badia et al., 2009). Stony bare slopes are found basically on hilltops, preferably at altitudes over $700 \mathrm{~m}$, and occupy 590 hectares, representing $4.3 \%$ of the surface of the natural park. Such rocky spots are often small and isolated, and frequented by park users (Bros, 2011), these factors increasing the vulnerability of snail populations. The comparison of stony bare slopes by aerial photographs and subsequent analyses indicates that these habitats have shrunk in the last 60 years, with a natural expansion of Holm oak reforestation. Plant succession in stony bare slopes starts by increasing the thickness of the leaf litter layer with the accumulation of litter from the nearby forest; over time, this process continues with the establishment of shrub species such as Cistus albidus and Rosmarinus officinalis, which in turn retain more soil and eventually allow the establishment of some arboreal species. This phenomenon is less noticeable in more sloped stony bare slopes where soil retention is not significant.

In the Mediterranean basin, the forest surface area has increased in the last century (Barbero et al., 1990). This is due in part to the abandonment of traditional agricultural activities, giving rise to subsequent natural revegetation (Lasanta and Vicente-Serrano, 2007; Moreira and Russo, 2007), as well as the extensive forestry usually made with allochthonous species such as eucalyptus and conifers. Although greater forest cover improves the quality of the habitat for most terrestrial Palaearctic gastropods considered to be intolerant to drought (Kerney and Cameron, 1999; Ström et al., 2009), this pattern does not fit certain species that prefer habitats with low vegetation cover such as many Xerocrassa species (e.g. Hermony et al., 1992; Graack, 2005).

Surprisingly, we also found Xerocrassa montserratensis and $X$. penchinati at burnt sites. These areas harbouring the two Xerocrassa species are precisely those with the lowest gastropod diversity and species richness in the park due to the fire impact on the landsnail community (Bros et al., 2011). Indeed, in our study area, wildfires drastically reduced snail-species richness and facilitated a shift of dominant species in favour of open-space species, this pattern leading to a juxtaposition of two different assemblages in burnt 


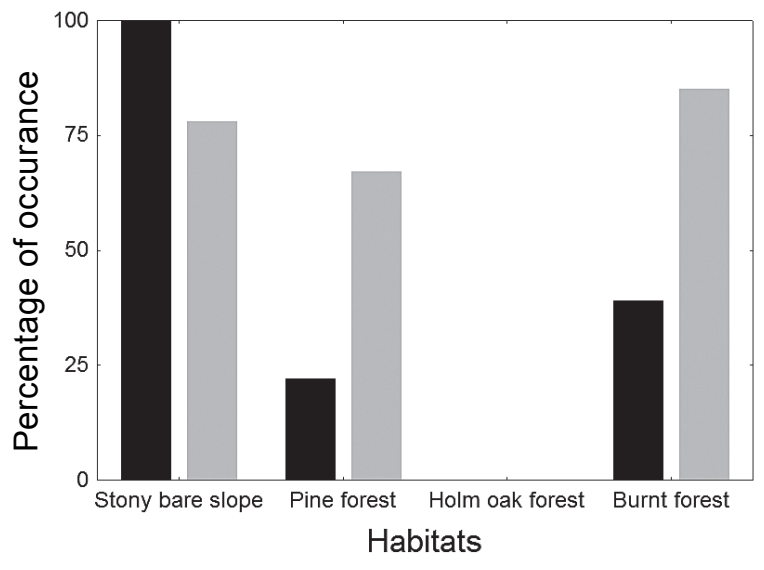

Fig. 4. Percentage of occurrence of X. montserratensis (black columns) and $X$. penchinati (grey columns) in Holm oak forest, pine forest, burnt, and stony bare slope sites.

and non-burnt areas (Santos et al., 2009). The severe impact of fire on land snails has been widely reported and is related mainly to changes in several environmental features of the habitat such as changes in vegetation structure, soil moisture, and $\mathrm{pH}$, as well as the loss of the leaf-litter layer (Nekola, 2002; Severs, 2005; Santos et al., 2009; Hylander, 2011; Bros et al., 2011). In Mediterranean areas where the fire regime has persisted over decades or centuries, land-snail communities appear highly altered and composed mainly of Mediterranean and xerophilous species (Kiss et al., 2004).
The presence of the two Xerocrassa species at burnt sites is noteworthy, given that before the fire in 2003, most of the burnt areas were dense pine and Holm oak forests. Therefore, the way in which Xerocrassa species colonize the burnt areas is still an open question, especially considering the low recolonization rates of gastropods from the unburnt edge of the fire (Santos $e t$ al., 2009). A plausible explanation is the existence of suitable microhabitats inside the forest for xerophilous species such as Xerocrassa snails. After the fire, the availability of cryptic refuges (Kiss and Magnin, 2003, 2006) facilitates the survival of snail populations. The environmental conditions at burnt sites contribute to the maintenance of xerophilous and open-area snails to the detriment of forest snails. This pattern has been previously highlighted in Mediterranean vertebrate groups (Herrando et al., 2003; Moreira and Russo, 2007) and bears extraordinary importance in terms of conservation, since many open-area species are threatened (e.g. Law and Dickman, 1998; Pino et al., 2000) and are endemic to the Mediterranean basin (Perevolotsky, 2006).

In summary, fire and natural reforestation may act as contrasting stressors for the presence of Xerocassa species due to differences found in vegetation and groundcover among habitats. Natural reforestation is closing stony bare slopes, thus reducing the most favourable habitats for xerophilous snails in the park, whereas wildfire seems to favour their population recovery. These results contribute significantly to our understanding of how natural processes mould Mediterranean communities, and consequently, our results

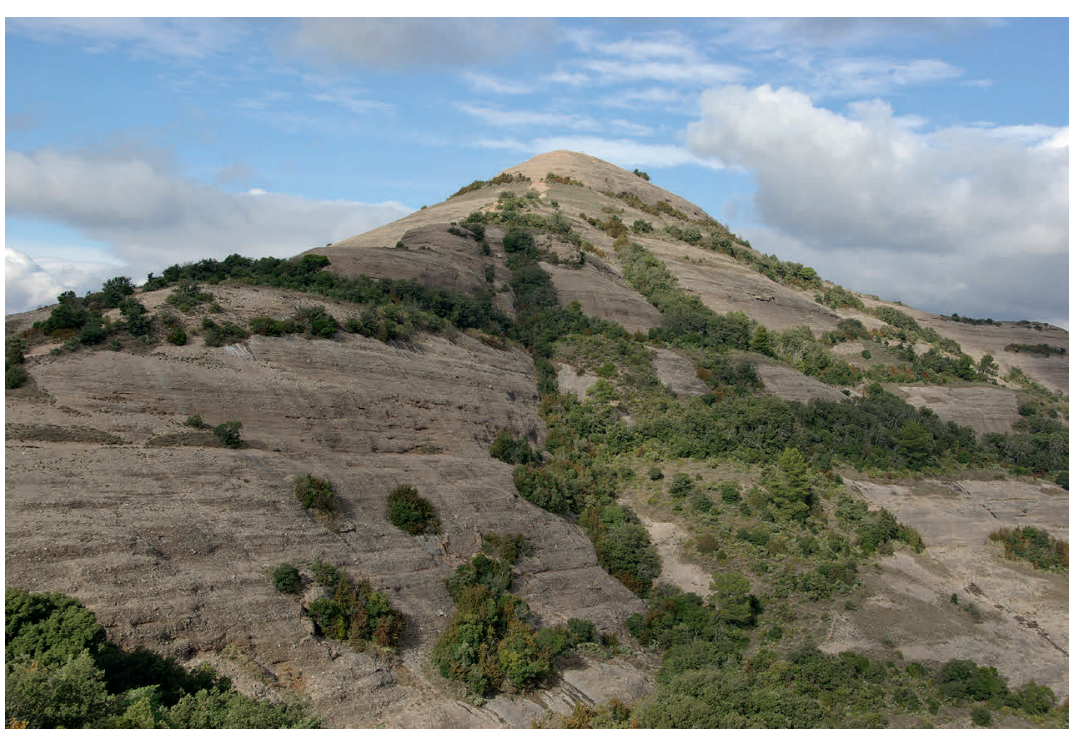

Fig. 5. Stony bare slopes in the Montcau, one of the most famous peaks in the Sant Llorenç del Munt i l'Obac Natural Park. Steep- and shallow-sloped stony bare slopes are surrounded by Holm oak forest. 
may have important implications for management and conservation. The natural dynamics in a natural park is clearly natural reforestation, although Xerocrassa is negatively responding to increased cover. For this reason, it is essential to consider several management approaches to control this tendency such as grazing or tree/brush cutting (although grazing has been recognized to have negative effects for land snails in nutrient-poor pastures, Boschi and Baur, 2007). In fact, several management measures have been started in the last 7 years in the natural park to mimic past land uses (e.g. grazing and logging in abandoned fields, Lobo et al., 2007). The final objective of this management is to enhance biodiversity by the maintenance of landscape mosaics (i.e. spatial heterogeneity) to avoid a uniform forest canopy (Lobo et al., 2007; Pino et al., 2000; Bartolomé et al., 2000, 2005). Management of lowslope stony bare slopes, the preferred habitat for Xerocrassa, can be especially important, and future studies should examine spatiotemporal changes in Xerocrassa presence and abundance in these habitats. Pintó and Panareda (1995) reported that stony bare slopes are the last step of forest degradation due to the human exploitation of Holm oak trees for wood, or the degradation of abandoned cropland and subsequent soil erosion. Over the long term, there is a natural revegetation process of low-slope stony bare slopes. Due to their importance, monitoring and conservation of stony bare slopes should be a priority management practice in the park. Accordingly, our study may give valuable insights into the management practices which may be applied to recover favourable habitats of threatened species such as Xerocrassa snails.

Reforestation practices throughout the Mediterranean have long relied on procedures borrowed from pine forestry (Pausas et al., 2004; Rey et al., 2009). Our results show that xerophilous species such as $X$. montserratensis may be harmed by this practice. In fact, extensive pine forests as a result of forestry processes seem to be low-quality habitats for several arthropod communities (Vance et al., 2007; Mateos et al., 2011). Extensive pine forests reduce habitats for open-area species in the Mediterranean basin (Preiss et al., 1997; Stefanescu et al., 2004). However, pine forests are prone to burning, and wildfires, though catastrophic for several components of the biota, provide new open areas and consequently facilitate the recolonization of open-space species (Herrando et al., 2003; Santos et al., 2009, Santos and Poquet, 2010). Future climate conditions are expected to increase fire frequency and extent (McKenzie et al., 2004), and the response of xerophilous and a priori drought-resistent snail species to repeated-fire regimes is unknown. In the present scenario, a balance between different environmental stressors may promote landscape heterogeneity, thereby increasing biodiversity at a regional scale (Plotnick and Gardner, 2002; Possingham et al., 2005). Wildlife reserves as Sant Llorenç del Munt i l'Obac Natural Park are suitable localities to apply management practices intended to produce landscape mosaics, hence facilitating the conservation of particular and sensible habitats for endangered species such as Xerocrassa land snails.

\section{Acknowledgements}

We are very grateful to the managers of the Sant Llorenç del Munt i l'Obac Natural Park for their collaboration, and especially Angel Miño, and Adrià Fabrega for their logistic support. We thank Albert Peris for his useful comments on an early draft of the manuscript, Miquel Casals for providing old photographs of popular stony monoliths in the park, and Iago Otero for their bibliographic suggestions. We are grateful to the two reviewers for their important suggestions, useful for improving the manuscript. David Nesbitt improved the English style. Xavier Santos was supported by a Beatriu de Pinós post-doctoral grant (2005/ BP-B1/10211, Catalan Government) during field sampling, and a post-doctoral grant (SFRH/BPD/73176/2010; Fundação para a Ciência e a Tecnologia, Portugal) during data analysis and paper writting.

\section{References}

Badia J, Bros V, Germain J, Gomez-Bolea A, Oms O, Vallès F. 2009. Sant Llorenç del Munt: el Montcau canal de les teixoneres. In: Les sortides naturalistes de la Institució Catalana d'Història Natural [available via http://ichn.iec.cat]

Bank, R. 2011. Fauna europaea project. Checklist of the land and freshwater Gastropoda of the Iberian peninsula (Spain, Portugal, Andorra, Gibraltar). [available via http://www. nmbe.ch]

Barbero M, Bonin G, Loisel R, Quézel P. 1990. Changes and disturbances of forest ecosystems caused by human activities in the western part of the mediterranean basin. Vegetatio 87: 151-153.

Bartolomé J, Franch J, Plaixats J, Seligman NG. 2000. Grazing alone is not enough to maintain landscape diversity in the Montseny Biosphere Reserve. Agriculture, Ecosystems and Environment 77: 267-273.

Bartolomé J, Plaixats J, Fanlo R, Boada M. 2005. Conservation of isolated Atlantic heathlands in the Mediterranean region: effects of land-use changes in the Montseny biosphere reserve (Spain). Biological Conservation 122: 81-88.

Blondel J, Aronson J, Boudiou JY, Boeuf G. 2010. The Mediterranean Basin. Biological diversity in space and time. Oxford: Oxford University Press. 
Bond WJ, Woodward FI, Midgley GF. 2005. The global distribution of ecosystems in a world without fire. New Phytologist 165: 525-538.

Boschi C, Baur B. 2007. Effects of management intensity on land snails in Swiss nutrient-poor pastures. Agriculture, Ecosystems and Environment 120: 243-249.

Bottema S, Entjes-Nieborg G, Van Zeist W. 1990. Man's role in the shaping of the eastern Mediterranean landscape. Rotterdam: Balkema.

Bradstock RA, Bedward M, Gill AM, Cohn JS. 2005. Which mosaic? A landscape ecological approach for evaluating between fire regimes, habitat and animals. Wildlife Research 32: 409-423.

Bragado D, Araujo R, Aparicio MT. 2010. Atlas y Libro Rojo de los Moluscos de Castilla-La Mancha. Organismo Autónomo Espacios Naturales de Castilla-La Mancha. Guadalajara: Junta de Comunidades de Castilla-La Mancha.

Brooks TM, Mittermeier RA, Mittermeier CG, Da Fonseca GAB, Rylands AB, Konstant WR, Flick P, Pilgrim J, Oldfield S, Magin G, Hilton-Taylor C. 2002. Habitat loss and extinction in the hotspots of biodiversity. Conservation Biology 16: 909-923.

Bros V. 2000. Els molluscs gasteròpodes (Mollusca, Gastropo$d a$ ) del massís de Sant Llorenç del Munt i la serra de l'Obac. Monografies 29: 87-95.

Bros V. 2006. Cargols terrestres (Gastropoda, Stylommatophora) del Parc Natural de la Muntanya de Montserrat (Barcelona, NE península Ibèrica). Arxius de Miscellània Zoològica 4: 1-41.

Bros V. 2011. Composició de la comunitat de mol-luscs de les codines en el Parc Natural de Sant Llorenç del Munt i l'Obac, i l'impacte del trepig i l'erosió en el Montcau. Pp. 51-60 in: VII Monografies de Sant Llorenç del Munt $i$ l'Obac. Barcelona: Diputació de Barcelona.

Bros V, Moreno-Rueda G, Santos X. 2011. Does postfire management affect the recovery of Mediterranean communities? The case study of terrestrial gastropods. Forest Ecology and Management 261: 611-619.

Broza M, Izhaki I. 1997. The impact of intense fire on the soil Arthropod community in Mediterranean pine forest in Israel: Time post-fire, seasonality and influence of tree species. International Journal of Wildland Fire 7: 317-325.

Buddle CM, Langor, DW, Pohl GR, Spence JR. 2006. Arthropod responses to harvesting and wildfire: Implications for emulation of natural disturbance in forest management. Biological Conservation 128: 346-357.

Clanzing S, Bertrand A. 2000. Trochoidea (Xerocrassa) penchinati (Bourguiguignat, 1868), (Gastropoda: Hygromiidae: Geometrinae) un mollusque terrestres de la faune de France peu connu. Documents malacologiques 1: 11-15.

Cook A. 2001. Behavioural Ecology: On doing the right thing, in the right place at the right time. Pp. 447-487 in: Barker GM, ed., The biology of terrestrial molluscs. New York: CABI Publishing.

Coppolino ML. 2010. Strategies for Collecting Land Snails and Their Impact on Conservation Planning. American Malacological Bulletin 28: 97-103.

Davies KF, Margules CR, Lawrence JF. 2004. A synergistic effect puts rare, specialized species at greater risk of extinction. Ecology 85: 265-271.
Dedov I, Stoyanov IL, Penev L, Harvey JA, Van der Putten WH, Bezemer TM. 2006. Long-term effects of sowing high or low diverse seed mixtures on plant and gastropod diversity. Acta Oecologica 30: 173-181.

Driscoll DA, Henderson MK. 2008. How many common reptile species are fire specialists? A replicated natural experiment highlights the predictive weakness of a fire succession model. Biological Conservation 141: 460-471.

Driscoll DA, Lindenmayer DB, Bennett AF, Bode M, Bradstock RA, Cary GJ, Clarke MF, Dexter N, Fensham R, Friend G, Gill M, James S, Kay G, Keith DA, MacGregor C, Russel-Smith J, Salt D, Watson JEM, Williams RJ, York A. 2010. Fire management for biodiversity conservation: key research questions and our capacity to answer them. Biological Conservation 143: 1928-1939.

Dupouey JL, Dambrine E, Laffite JD, Moares C. 2002. Irreversible impact of past land use on forest soils and biodiversity. Ecology 83: 2978-2984.

Gaines WL, Lyons AL, Weaver K, Sprague A. 2011. Monitoring the short-term effects of prescribed fire on an endemic mollusk in the dry forests of the eastern Cascades, Washington, USA. Forest Ecology and Management 261: 1460-1465.

Giokas S. 2008. Shell surface adaptations in relation to water management in rock-dwelling land snails, Albinaria (Pulmonata: Clausiliidae). Journal of Natural History 42: 451465.

Goodfriend GA. 1986. Variation in land snail shell form and size and its causes: a review. Systematic Zoology 35: 204223.

Gotelli NJ, Entsminger GL. 2001. EcoSim: Null models software for ecology. Version 7.0. Acquired Intelligence Inc. \& Kesey-Bear. Jericho, VT 05465. [available via http://garyentsminger.com]

Graack W. 2005. Die Gattung Xerocrassa Monterosato 1892 (Mollusca, Hygromiidae) von Mallorca. Schriften zur Malakozoologie 22: 1-64.

Heller J. 2001. Life history strategies. Pp- 413-445 in: Barker GM, ed., The biology of terrestrial molluscs. New York: CABI Publishing.

Hermony I, Shachak M, Abramsky Z. 1992. Habitat distribution in the desert snail Trochoidea seetzenii. Oikos 64: 516-522.

Herrando S, Brotons L, Llacuna S. 2003. Does fire increase the spatial heterogeneity of bird communities in Mediterranean landscapes? Ibis 145: 307-317.

Hoekstra JM, Boucher TM, Ricketts TH, Roberts C. 2005. Confronting a biome crisis: global disparities of habitat loss and protection. Ecology Letters 8: 23-29.

Hylander K. 2011. The response of land snail assemblages below aspens to forest fire and clear-cutting in Fennoscandian boreal forests. Forest Ecology and Management 261: 18111819.

ICHN. 2008. Invertebrats que requereixen mesures de conservació a Catalunya. Barcelona: Institució Catalana d'Història Natural. [available via http://ichn.iec.cat].

Kappes H, Topp W, Zach P, Kulfan J. 2006. Coarse woody debris, soil properties and snails (Mollusca: Gastropoda) in European primeval forests of different environmental conditions. European Journal of Soil Biology 42: 139-146.

Kappes H, Clausius A, Topp W. 2012. Historical small-scale surface structures as a model for post-mining land reclamation. Restoration Ecology 20: 322-330. 
Kerney MP, Cameron RAD. 1999. Escargots et limaces d'Europe du Nord-Ouest. Bertrand A. translation and adaptation. Paris et Neuchâtel: Delachaux et Niestlé.

Kiss L, Magnin F. 2003. The impact of fire on some mediterranean land snail communities and patterns of post-fire recolonisation. Journal of Molluscan Studies 69: 43-53.

Kiss L, Magnin F. 2006. High resilience of Mediterranean land snail communities to wildfires. Biodiversity and Conservation 15: 2925-2944.

Kiss L, Magnin F, Torre F. 2004. The role of landscape history and persistent biogeographical patterns in shaping the responses of Mediterranean land snail communities to recent fire disturbances. Journal of Biogeography 31: 145-157.

Labaune C, Magnin F. 2002. Pastoral management vs. land abandonment in Mediterranean uplands: impact on land snail communities. Global Ecology and Biogeography 11: 237-245.

Lasanta T, Vicente-Serrano SM. 2007. Cambios en la cubierta vegetal en el Pirineo aragonés en los últimos 50 años. Pirineos 162: 125-154.

Law BS, Dickman CR. 1998. The use of habitat mosaics by terrestrial vertebrate fauna: implications for conservation and management. Biodiversity and Conservation 7: 323333.

Lepš J, Šmilauer T. 2003. Multivariate Analysis of Ecological Data using CANOCO. Cambridge: Cambridge University Press.

Lobo A, Vega C, Baró F. 2007. Selecció d'espais oberts a recuperar i propostes d'ús: una aproximació per anàlisi espacial i multicriteri. Reports on Environmental Sciences 6. [available via http://www.recercat.net]

Magnin F, Tatoni T, Roche P, Baudry J. 1995. Gastropod communities, vegetation dynamics and landscape changes along an old-field succession in Provence, France. Landscape and Urban Planning 31: 249-257.

Martínez-Ortí A. 2011. Xerocrassa montserratensis. In: IUCN 2011. IUCN Red List of Threatened Species. Version 2011.2. [available via www.iucnredlist.org]

Martínez-Ortí A, Bros V. 2011. Taxonomical clarification status of the Iberian endemic Xerocrassa montserratensis/betulonensis (Gastropoda, Pulmonata, Hygromiidae). Pp. 88 in: 6th Congress of the European Malacological Societies. Vitoria-Gasteiz.

Mateos E, Santos X, Pujade-Villar J. 2011. Taxonomic and functional responses to fire and post-fire management of a Mediterranean Hymenoptera community. Environmental Management 48: 1000-1012.

McKenzie D, Gedalof Z, Peterson DL, Mote P. 2004. Climatic change, wildfire, and conservation. Conservation Biology 18: 890-902.

McKinney ML. 1997. Extinction vulnerability and selectivity: combining ecological and paleontological views. Annual Review of Ecology and Systematics 28: 495-516.

Moreira F, Russo D. 2007. Modelling the impact of agricultural abandonment and wildfires on vertebrate diversity in Mediterranean Europe. Landscape Ecology 22: 1461-1476.

Moreno JM, Oechel WC, eds. 1994. The role of fire in Mediterranean-type ecosystems. New York: Springer-Verlag.

Moreno-Rueda G. 2011. Revisión del estatus de conservación del caracol amenazado Iberus gualtieranus gualtieranus. Zoologica baetica 22: 69-85.
Moretti M, Obrist MK, Duelli P. 2004. Arthropod biodiversity after forest fires: winners and losers in the winter fire regime of the southern Alps. Ecography 27: 173-186.

Nekola JC. 2002. Effects of fire management on the richness and abundance of central North American grassland land snail faunas. Animal Biodiversity and Conservation 25: 53-56.

Ondina P, Mato S. 2001. Influence of vegetation type on the constitution of terrestrial gastropod communities in Northwest Spain. Veliger 44: 8-19.

Panareda JM, Pintó J. 1997. Sant Llorenç del Munt. Visió geogràfica. Descoberta geogràfica 4. Vic: Eumo Editorial.

Parody JM, Cuthbert FJ, Decker EH. 2001. The effect of 50 years of landscape change on species richness and community composition. Global Ecology and Biogeography 10: 305-313.

Pausas JG, Blade C, Valdecantos A, Seva JP, Fuentes D, Alloza JA, Vilagrosa A, Bautista S, Cortina J, Vallejo R. 2004. Pines and oaks in the restoration of Mediterranean landscapes of Spain: New perspectives for an old practice - a review. Plant Ecology 171: 209-220.

Perevolotsky A. 2006. Integrating landscape ecology in the conservation of Mediterranean ecosystems: the Israeli experience. Israel Journal of Plant Science 53: 203-213.

Pino J, Rodà F, Ribas J, Pons X. 2000. Landscape structure and bird species richness: implications for conservation in rural areas between natural parks. Landscape and Urban Planning 49: 35-48.

Pintó J, Panareda JM. 1995. Memòria del mapa de vegetació de Sant Llorenç del Munt (Barcelona). Sèrie mapes, núm. 1. Barcelona: Aster editorial.

Plotnick RE, Gardner RH. 2002. A general model for simulating the effects of landscape heterogeneity and disturbance on community patterns. Ecological Modelling 147: 171197.

Possingham HP, Franklin J, Wilson K, Regan TJ. 2005. The Roles of Spatial Heterogeneity and Ecological Processes in Conservation Planning. Pp. 389-406 in: Lovett GM, Turner MG, Jones CG, Weathers KC, eds, Ecosystem Function in Heterogeneous Landscapes. New York: Springer.

Preiss E, Martin J-L, Debussche M. 1997. Rural depopulation and recent landscape changes in a Mediterranean region: Consequences to the breeding avifauna. Landscape Ecology 12: 51-61.

Rey PJ, Siles G, Alcántara JM. 2009. Community-level restoration profiles in Mediterranean vegetation: nurse-based vs. traditional reforestation. Journal of Applied Ecology 46: 937-945.

Ribeiro R, Santos X, Sillero N, Carretero MA, Llorente GA. 2009. Biodiversity and land uses: Is agriculture the biggest threat in reptiles' assemblages? Acta Oecologica 35: 327-334.

Sala OE, Chapin FS, Armesto JJ, Berlow E, Bloomfield J, Dirzo R, Huber-Sanwald E, Huenneke LF, Jackson RB, Kinzig A, Leemans R, Lodge DM, Mooney HA, Oesterheld M, Poff NL, Sykes MT, Walker BH, Walker M, Wall DH. 2000. Global Biodiversity Scenarios for the Year 2100. Science 287: 1770-1774.

Santos X, Poquet JM. 2010. Ecological succession and habitat attributes affect the post-fire response of a Mediterranean reptile community. European Journal of Wildlife Research 56: 895-905. 
Santos X, Brito JC, Sillero N, Pleguezuelos JM, Llorente GA, Fahd S, Parellada X. 2006. Inferring conservation status with ecological modelling techniques and GIS: an application with Vipera latastei in the Iberian Peninsula. Biological Conservation 130: 416-425.

Santos X, Bros V, Miño A. 2009. Recolonization of a burned Mediterranean area by terrestrial gastropods. Biodiversity and Conservation 18: 3153-3165.

Schilthuizen M. 2011. Community ecology of tropical forest snails: 30 years after Solem. Contributions to Zoology 80: $1-15$.

Severs PM. 2005. Response of terrestrial mollusc community to an autumn prescribed burn in rare wetland prairie of western Oregon, USA. Journal of Molluscan Studies 71: 181-187.

Stefanescu C, Herrando S, Páramo F. 2004. Butterfly species richness in the north-west Mediterranean Basin: the role of natural and human-induced factors. Journal of Biogeography 31: 905-915.

Ström L, Hylander K, Dynesius M. 2009. Different long-term and short-term responses of land snails to clear-cutting of boreal stream-side forests. Biological Conservation 142: 1580-1587.

Ter Braak CJF, Šmilauer P. 2002. CANOCO Reference Manual and CanoDraw for Windows User's Guide: Software for
Canonical Community Ordination (Version 4.5). Ithaca: Microcomputer Power.

Trabaud L, Prodon R. 2002. Fire and biological processes. Leiden: Backhuys.

Vance CC, Smith SM, Malcolm JR, Huber J, Bellocq MI. 2007. Differences between forest type and vertical strata in the diversity and composition of Hymenpteran families and Mymarid Genera in Northeastern Temperate Forests. Environmental Entomology 36: 1073-1083.

Ward-Booth JF, Dussart GBJ. 2001. Consistency in handsearching for terrestrial snails. Journal of Molluscan Studies 67: 502-506.

Watters GT, Menker T, O'dee SH. 2005. A comparison of terrestrial snail faunas between strip-mined land and relatively undisturbed land in Ohio, USA - an evaluation of recovery potential and changing faunal assemblages. Biological Conservation 126: 166-174.

Whelan RJ. 1995. The Ecology of fire. Cambridge: Cambridge University Press.

Received: 10 February 2012

Revised and accepted: 7 June 2012

Published online: 24 Augustus 2012

Editor: M. Schilthuizen

\section{On-line supplementary material}

S1. Redundancy analysis plot of the association between vegetal plus soil variables and the four habitats sampled. 
S1. Redundancy analysis plot of the association between vegetal plus soil variables and the four habitats sampled.

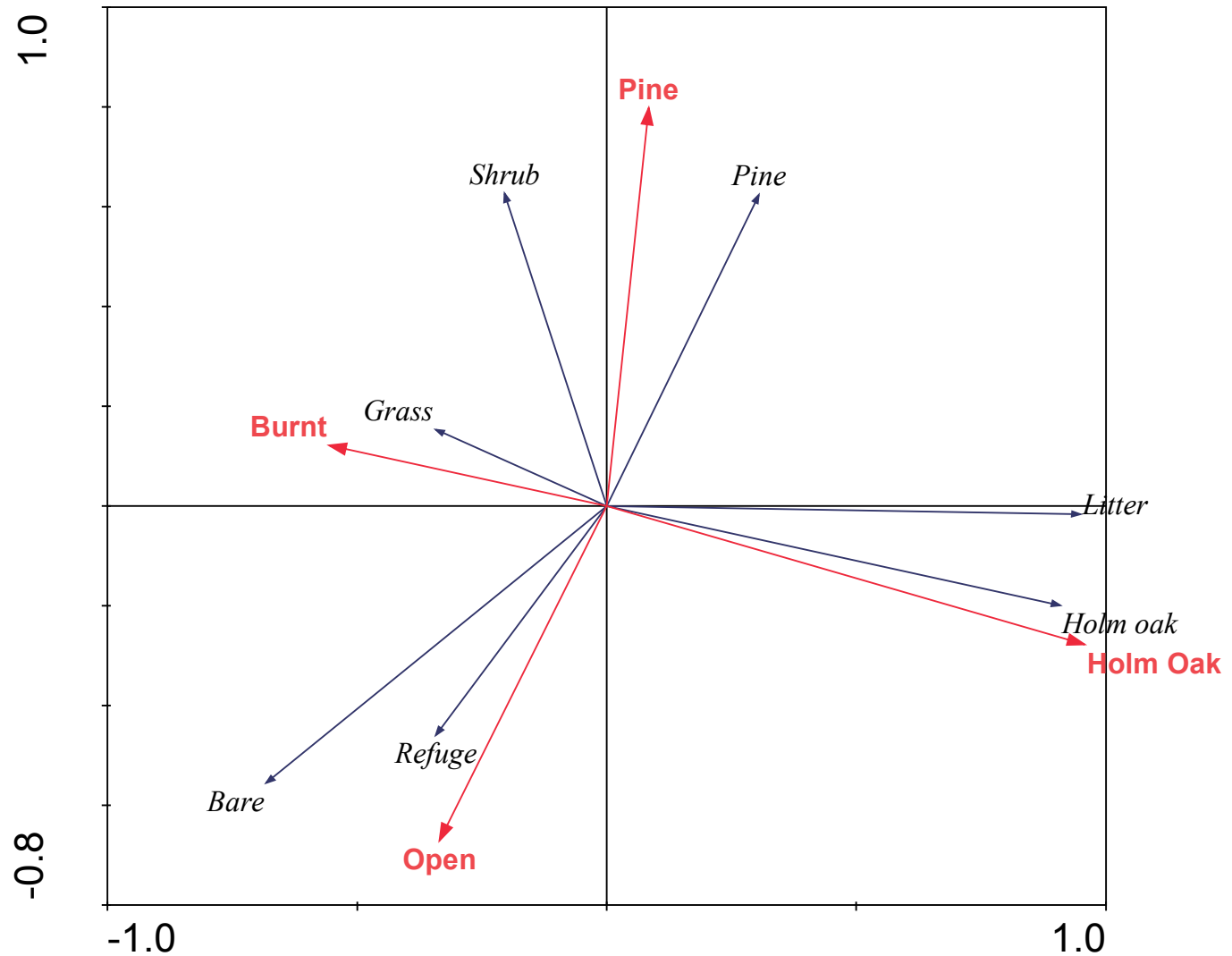

